\title{
Presence of Maedi-Visna in Costa Rican sheep flocks
}

\author{
Rodolfo Villagra-Blanco ${ }^{a, *}$, Gaby Dolz ${ }^{a}$, Antony Solórzano-Morales ${ }^{a}$, \\ Alejandro Alfaro ${ }^{\mathrm{b}}$, Danilo Montero-Caballero ${ }^{\mathrm{c}}$, Juan José Romero-Zúñiga ${ }^{\mathrm{a}}$ \\ a Programa de Investigación en Medicina Poblacional, Escuela de Medicina Veterinaria, Universidad Nacional (UNA), Heredia, Costa Rica \\ b Servicio de Patología, Escuela de Medicina Veterinaria, UNA, Heredia, Costa Rica \\ c Cátedra de Salud de Hato y Control de la Producción, Escuela de Medicina Veterinaria, UNA, Heredia, Costa Rica
}

\section{A R T I C L E I N F O}

\section{Article history:}

Received 28 August 2014

Received in revised form 12 January 2015

Accepted 14 January 2015

Available online 22 January 2015

\section{Keywords:}

Lentivirus

PCR

ELISA

Ovines

Small ruminants

Costa Rica

\begin{abstract}
A B S T R A C T
A total of 359 sheep serum samples from 15 farms were analyzed for the presence of antibodies against Maedi Visna Virus (MVV) by Enzyme-linked Immunosorbent Assay (ELISA). Additionally, a survey was applied to the sheep owners in order to determine management measures and presence of clinical symptoms of Maedi-Visna in the flocks. Logistic regression with random effects was performed to assess risk factors to seropositivity. Seven serum samples were positive to MVV belonging to six flocks, determining low flock seropositivity (0 to $7.1 \%$ ). Only one of the five regions studied was negative, determining low overall prevalence $(1.95 \%)$ and low positivity by region $(0.0 \%$ to $0.84 \%)$. One seropositive animal with symptoms related to MVV was sacrificed for necropsy. An enlargement of mesenteric and celiac lymph nodes was determined, histopathology of lungs revealed acute interstitial pneumonia. Analysis of organs, fluids and blood of this sheep by Polymerase Chain Reaction (PCR) to detect MVV yielded negative results. In order to confirm the serological results, serum and blood samples from two remaining seropositive animals were analyzed six months later, one resulted seronegative and the other seropositive in ELISA, but both negative in PCR. No risk factors were associated to seropositivity. Since MVV produces latency, we conclude, that the positive serological results were due to false positive reactions. Even though, $52.0 \%$ of the participating farms had introduced animals, embryos, or semen from other farms or from abroad without any sanitary certification, MVV seems to be present in Costa Rica probably in a very low prevalence. Further studies are required to implement control measures and prevent the spread of the disease.
\end{abstract}

(c) 2015 Elsevier B.V. All rights reserved.

\section{Introduction}

Maedi-Visna (MV) is a multisystemic-chronic ovine disease caused by non-oncogenic retrovirus, the Maedi Visna Virus (MVV) which belongs together with the Caprine Arthritis Encephalitis Virus (CAEV) to the Small Ruminant Lentivirus (SRLV). Both virus shows a long incubation period, which can last from months to years, causing a

\footnotetext{
* Corresponding author. Tel.: +506 25624508.

E-mail address: ravb870@gmail.com (R. Villagra-Blanco).
}

lifelong infection in small ruminants that develops to chronic progressive pneumonia, lymphocytic mastitis, arthritis and nervous disorders (Pepin et al., 1998; DeMartini et al., 2000; Fournier et al., 2006).

In the Americas, MVV infection was first described in Canada, where the first case was reported in 1972 in a sheep flock from Quebec (Bellavance et al., 1974). SRLV was later detected in different states of United States of America (Cutlip et al., 1977; Campbell et al., 1994) and Mexico (Molina et al., 1986). Currently in South America, Chacón and Naranjo (2004) published the first case of MV in Chile in a sheep flock and one year later MVV 
was detected in imported Milchschaff sheep, determining flock prevalences from 20.5\% to 32.5\%. Recently, Martínez et al. (2011) detected two positive MVV sheep in Bahia, and a seroprevalence of $2.7 \%$ of MVV was determined in sheep flocks Northwest of Sao Paolo, Brazil (Martínez et al., 2011). The presence of this agent has also been documented in other South American nations such as Peru (Snyder et al., 1983; Rosadio et al., 1984) and Argentina (Robles et al., 2003). However, in the vast majority of developing countries the MV status in sheep flocks is still unknown, principally due to the absence of diagnostic testing and surveillance programs (Pugh, 2002). Clinical signs of MVV are not pathognomonic, therefore pathological or laboratorial analyses are needed in order to detect the disease. Techniques performed in the laboratory may be classified as direct (evidence of the virus or viral antigens) or indirect ones (evidence of the antibodies through inmmunoenzimatic assays) (Peterhans et al., 2004). The detection of MVV by molecular techniques like Polymerase Chain Reaction (PCR) has the advantage that it is a highly sensitive and specific technique, however expensive, and therefore used mainly for research (Pepin et al., 1998). Meanwhile, Enzyme-linked Immunosorbent Assay (ELISA) allows early detection of antibodies through its high sensitivity, at the same time, evaluation of large number of samples in a short time ( 2 to $3 \mathrm{~h}$ ) is possible, being also less expensive than PCR. Sheep and goats started seroconversion (antibody production) from two weeks to eight months post-infection (Peterhans et al., 2004).

In Costa Rica, the presence of CAEV has been reported by Jiménez-Sánchez et al. (1992) and George (1995), and was later confirmed by Fallas et al. (2009). Presence of MVV in Costa Rican sheep flocks had not been studied to date, although the ovine population increased 51\% from 1999 to 2010 (FAO, 2012). Due to the lack of reports on the presence of MVV in Costa Rica, the aim of this study was to determine the presence of MVV in this Central American country using ELISA and PCR, and to assess risk factors to seropositivity.

\section{Materials and methods}

\subsection{Sample size}

The sample size was calculated with an estimated population of 25,000 animals distributed in 138 sheep flocks in Costa Rica (1.0\% overall expected prevalence, $95.0 \%$ confidence level), yielding a total of 300 samples to analyze; however, a total of 359 animals were surveyed. Within each flock, the number of animals to be sampled was calculated, to determine presence or absence of MVV, based on a $10.0 \%$ expected prevalence inside each flock (Chacón and Naranjo, 2004), 95.0\% confidence level and using the formula described by Cannon and Roe (1982). The study was conducted in 15 Costa Rican sheep flocks, randomly selected, willing to participate on a voluntarily basis. According proportional allocation, the farms were distributed as follows: seven in the Central region (46.0\%), two in the Chorotega region (13.5\%), two in the Central Pacific region (13.5\%), two in the Huetar Norte region (13.5\%) and two in the Huetar Atlántica region (13.5\%). The Brunca region was not analyzed, since it was no possible to find farms willing to participate in this study (Fig. 1).

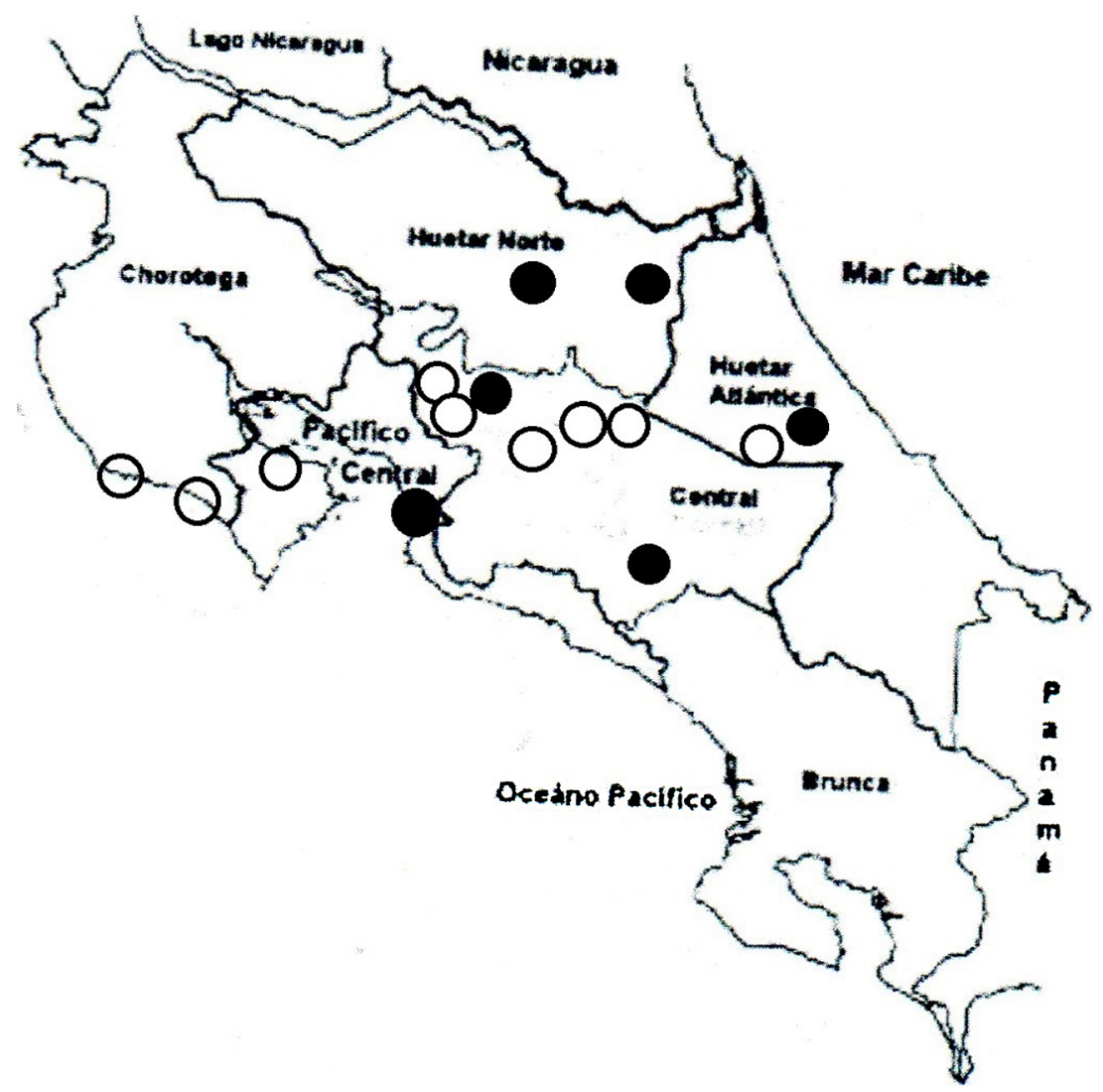

Fig. 1. Location of the participating farms (black and white dots) and flocks with MVV seropositive sheep (black dots) within the four analyzed regions of Costa Rica. 


\subsection{Studied population}

Most of the analyzed sheep flocks were used commercially (87\%), to produce tropical hair breed lambs (100\%), and these animals were maintained mainly intensively (93\%). The sampled sheep breeds were Dorper, Pellybuey, Kathadin, Blackbelly, Texel, Suffolk, Santa Ines and their mixes. No commercial milk production was recorded.

\subsection{Sample collection and survey}

The blood sampling was performed from the jugular vein. Tubes were transported using coolers for keeping a temperature between $5{ }^{\circ} \mathrm{C}$ and $10^{\circ} \mathrm{C}$. In the laboratory, the samples were centrifuged for $5 \mathrm{~min}$ at $10,000 \times g$ and sera were frozen at $-20^{\circ} \mathrm{C}$ until processing by ELISA. Immediately after sampling, a questionnaire was applied to the farmers, to get information about housing, lamb husbandry, management, presence of clinical signs, and basic knowledge on SRLV. Of the total of seropositive animals, one animal was sacrificed immediately for necropsy, and organs (lymph nodes, udder, meninges and lung), fluids (cerebrospinal and synovial), and blood sample were analyzed by PCR. Serum and whole blood samples from two surviving seropositive animals were analyzed six months later by ELISA and PCR, respectively, whereas the other remaining seropositive animals were sacrificed or sold, and could not be analyzed.

\subsection{Enzyme-linked Immunosorbent Assay (ELISA)}

The Maedi-Visna IDScreen ${ }^{\circledR}$ Indirect ELISA from IDVet ${ }^{\circledR}$ (Montpellier France) was used. This assay reported a sensitivity and specificity of $100 \%$ (Comtet et al., 2010). The methodology recommended by the manufacturer was used.

\subsection{Polymerase chain reaction $(P C R)$}

Genomic DNA from tissues (25-30 mg), liquids (200 $\mu \mathrm{l})$, and buffy coat fractions of blood samples $(200 \mu \mathrm{l})$ were extracted using QIAamp ${ }^{\circledR}$ DNA mini kit (Qiagen, Mississauga, Ontario, Canada), and following the manufacturer's protocol. The DNA was subjected to endpoint PCR, to amplify a sequence in the long terminal repeat (LTR) region of the MV provirus as described by Extramiana et al. (2002). Forward primer 5'-TGACACAGCAAATGTAACCGCAAG-3' and reverse primer 5'CCACGTTGGGCGCCAGCTGCGAGA-3', that specifically amplify a $291 \mathrm{bp}$ fragment, were used. Proviral DNA of MVV, donated by the Clinic for Swine, Small Ruminants and Forensic Medicine and Ambulatory Service, Tierärztliche Hochschule Hannover, Germany, was used as positive control; whereas water (Thermo Scientific, Waltham, USA) was used as negative control.

\subsection{Statistical analysis}

Frequencies of the general characteristics and management practices of the sheep flocks were calculated. To assess the relationship between MVV and the management practices, the odds ratio (OR) was calculated using a mixed effects logistic regression, being the sheep flock the random variable. Due the small amount of positive samples, only an univariable analysis was performed for each independent variable. The data was analyzed using SAS/STAT ver. 9.2 (SAS Institute Inc.).

\section{Results}

From a total of 359 serum samples analyzed with ELISA, seven animals (1.95\%) reacted positive. No sheep was detected with weak positive results. Seropositive animals were detected in four (Central, Huetar Atlántica, Pacífico Central and Huétar Norte) out of five regions analyzed (Fig. 1). Seropositivity in these regions was established between $0.0 \%$ and $0.84 \%$. In addition, no seropositive sheep was found on farms in the Chorotega region. The seven seropositive sheep were found in six different farms, determining low positivity percentages inside flocks ( $0 \%$ to $7.1 \%$ ) (Table 1 ). In only one out of 15 farms analyzed, two positive
Table 1

Number and percentage of animals analyzed and distribution of seropositive individuals according to flocks and regions.

\begin{tabular}{lrrrl}
\hline Region & Flock & Animals & $\begin{array}{l}\text { Animals } \\
\text { tested (\%) }\end{array}$ & $\begin{array}{l}\text { Positive } \\
\text { animals (\%) }\end{array}$ \\
\hline Huetar & 1 & 200 & $21(5.9)$ & $1(4.8)$ \\
Norte & 2 & 131 & $26(7.2)$ & $1(3.9)$ \\
Chorotega & 3 & 115 & $25(7.0)$ & $0(0.0)$ \\
Huetar Atlántico & 4 & 140 & $26(7.2)$ & $0(0.0)$ \\
Pacífico Central & 5 & 30 & $20(5.6)$ & $1(5.0)$ \\
& 7 & 350 & $27(7.5)$ & $0(0.0)$ \\
Central & 8 & 500 & $27(7.5)$ & $0(0.0)$ \\
& 9 & 80 & $28(7.8)$ & $1(3.6)$ \\
& 10 & 103 & $25(7.0)$ & $0(0.0)$ \\
& 11 & 136 & $25(6.7)$ & $0(0.0)$ \\
& 12 & 100 & $25(7.5)$ & $0(0.0)$ \\
& 13 & 220 & $26(7.2)$ & $0(0.0)$ \\
& 14 & 300 & $28(7.8)$ & $2(7.1)$ \\
Total & 15 & 4 & $4(1.1)$ & $0(0.0)$ \\
\hline
\end{tabular}

animals were detected, while in the remaining five farms only one seropositive animal was determined.

The descriptive analysis of the seven seropositive animals is shown in Table 2. The seropositive sheep were two males and five females, between two to seven years old, only three showed respiratory symptoms at the time of sampling, no nervous disorders were recorded. Four seropositive animals were recently introduced to the farms, while only one animal was born on the farm, and in the remaining two cases the origin of the animals was unknown. One seropositive animal that presented history of consecutive abortions, agalactia, progressive loss of body condition, despite carrying a rigorous deworming protocol, and respiratory distress, without presenting mucopurulent exudates, was euthanized. The necropsy determined enlargement of mesenteric and celiac lymph nodes, histopathology revealed acute interstitial pneumonia with lymphocytes and macrophages in the alveolar interstitium. No alterations in nervous tissue, udder or joints were determined. The analysis of lymph nodes, udder, meninges, lung, fluids (cerebrospinal and synovial) and blood samples from this sheep by PCR yielded negative results. In 2014, six months later, blood and serum samples of two remaining seropositive sheep from flock 14 were analyzed, and resulted negative in PCR, whereas in ELISA one was found seronegative and other seropositive (Table 2).

The survey revealed that $71.0 \%$ of the farms applied restrictions to access the sheep pens, whereas eight farmers $(56.0 \%)$ had exclusive pens for lambs and quarantine areas. More than half of the farmers (52.0\%) claimed to have animals or semen brought from abroad without any sanitary control or certification that animals or semen were free of SRLV. Loaning males between farms was practiced by $59.0 \%$ of the flocks. Farmers separated animals with mastitis (62.0\%), avoided mastitic milk for feeding lambs (78.0\%), and used milk replacer (79.0\%). Goat (37.0\%) and cow (22.0\%) milk were used mainly as replacer for lambs, either milk from CAEV seronegative goats $(7.0 \%)$ or milk from goats with unknown SRLV serostatus (93.0\%). 
Table 2

Descriptive analysis of seropositive sheep to MVV from Costa Rica.

\begin{tabular}{|c|c|c|c|c|c|c|c|}
\hline Positive animal & 1 & 2 & 3 & 4 & 5 & 6 & 7 \\
\hline Flock Number & 1 & 2 & 5 & 8 & 13 & 14 & 14 \\
\hline ELISA 2013 & + & + & + & + & + & + & + \\
\hline ELISA 2014 & ND & ND & ND & ND & ND & + & - \\
\hline PCR & ND & ND & ND & Negative & ND & Negative & Negative \\
\hline Sex & Female & Female & Male & Female & Female & Male & Female \\
\hline Age (years) & 7 & 3.4 & 3 & 3 & 3 & 2 & 2 \\
\hline Origin & OF & OF & $\mathrm{OF}$ & OF & SF & ND & ND \\
\hline Nasal discharge & + & + & + & & & & \\
\hline Forced breathing & + & + & + & + & & & \\
\hline \multicolumn{8}{|l|}{ Nervous disorders } \\
\hline Agalactia & & + & & + & & & \\
\hline \multicolumn{8}{|l|}{ Arthritis } \\
\hline Abortions & & + & & + & & & \\
\hline Final destiny & Sacrificed & Died & Died & Necropsy & Sold & Separated & Separated \\
\hline
\end{tabular}

ND: not determined, OF: other flock, SF: same flock.

The restricted suckling was performed by $21.0 \%$ of the farmers; none of them had established a bank of sheep colostrum. However, many producers were using the same needle in various animals (67.0\%) and only $42.0 \%$ disinfected the tattoo machine. Most of the farmers recorded respiratory signs (64.0\%), indurative mastitis (65.0\%), only $36.0 \%$ reported nervous disorders and $29.0 \%$ ataxia in their flocks in the past. Clinical cases of arthritis were observed only in two (13.0\%) of the 15 flocks. When the farmers were questioned about their knowledge about SRLV, 53.0\% answered never having heard of those viruses, whereas $26.0 \%$ knew about CAEV and only $21.0 \%$ knew about both viruses. However, despite these results, no statistical association between the seropositive animals and the analyzed risk factors were found in the present study.

\section{Discussion}

The global seropositivity determined in this study (1.95\%) is similar to that described by Costa et al. (2007), where six out of 558 sheep analyzed with agar gel immunodiffusion assay (AGID) were positive, establishing a seropositivity of $1.1 \%$ in Pernambuco, Brazil. Lombardi et al. (2009) and Martínez et al. (2011) confirmed these low seroprevalences ( $0.3 \%$ and $2.7 \%$, respectively) in 909 and 444 sera analyzed with AGID in Brazil. These authors concluded however, that even though the prevalences were low, the disease should not be underestimated, since it causes big losses in the national sheep production and leads to serious international repercussions. Although a possible low global seropositivity of MVV was established in Costa Rica, a wide geographical distribution was determined, which also coincides with the studies conducted in Brazil, pointing out the difficulty of finding seroreactors in sheep populations with low prevalence of the agent (Costa et al., 2007; Lombardi et al., 2009; Martínez et al., 2011).

An uncontrolled movement of animals was the reason of distribution of the agent worldwide. Most of the Costa Rican sheep farmers stated to buy animals from abroad, and to exchange animals between farms, without sanitary control or serological examination, which could explain the wide distribution of the agent within the country (Gjerset et al., 2007). Most of the analyzed farms maintained their animals in a very intensive management, with limited space and poor ventilation of pens, low availability of forage and poor health indicators. These conditions favor the spread of MVV within the flock (Hüttner et al., 2010; Leginagoikoa, 2010).

Although $10.0 \%$ prevalence was expected within each flock, only one farm showed a seropositivity of $7.1 \%$; whereas seropositivity of the remaining five farms ranged between 3.6\% and 5.0\%. These results indicate that in Costa Rica the seroprevalence of MVV seems to be low. On the other hand, the results could be due to false positive reactions in ELISA, since three seropositive animals tested with PCR yielded negative results; and one seropositive animal retested six months later yielded negative results in ELISA. Since this lentivirus shows a long incubation period, it is frequent, that MVV infected sheep did not show any sign of disease, sometimes throughout its life. However, it represents a source of infection within the flock (De la Concha-Bermejillo, 1997). This is an important argument that justifies the serological surveillance, since MVV occurs with non-pathognomonic signs that are often confounded with infections caused by secondary agents (Synge and Ritchie, 2010).

The clinical evaluation of seropositive MVV sheep determined respiratory distress without fever in three out of seven seropositive animals aged between three to seven years. These finding were in accordance with Martínez et al. (2011). It also agrees with studies from De la ConchaBermejillo (1997) and Menzies (2006), who reported the same respiratory signs in seropositive MVV sheep as is determined in the present study. Furthermore, the histopathological findings were consistent with the data described by Peterhans et al. (2004). Finally, the survey determined relevant risk factors in sheep flocks from Costa Rica (Peterhans et al., 2004; Lombardi et al., 2009; Leginagoikoa, 2010), particularly the improper use of needles, earmarks, and disinfection of tattoo machines and the lack of hygiene during milking (Leginagoikoa, 2010). The low number of seropositive animals and their distribution in different strata of analyzed farm management risk factors do not yield reliable statistical association.

We conclude that positive serological results were likely due to false positive reactions and that MVV is probably 
absent in Costa Rica or present in a very low prevalence. We recommend to carry out more studies to establish the presence or absence of MVV and seroprevalence of this agent in Costa Rica, in order to implement control measures to prevent the entry of the virus into the country, or to prevent the spread and eradicate the disease.

\section{Conflict of interest statement} exists.

The authors have declared that no conflict of interest

\section{Acknowledgements}

We would like to thank Prof. Dr. Michael Wendt of the Clinic for Pigs, Small Ruminants, Forensic Medicine and Ambulatory Service of the Tierärztliche Hochschule Hannover, Germany, for his valuable advice and the donation of MVV positive controls for PCR. Thanks to all farmers that participated in this research.

\section{References}

Bellavance, R.D., Turgeon, J., Phaneuf, B., Sauvageau, R., 1974. Pneumonie interstitielle et progressive du mouton. Can. Vet. J. 15, 293-297.

Campbell, J.R., Menzies, P.L., Waltner-Toews, D., Walton, J.S., Buckrell, B.C. Thorsen, J., 1994. The seroprevalence of Maedi-Visna in Ontario sheep flocks and its relationship to flock demographics and management practices. Can. Vet. J. 35, 39-44.

Cannon, R.M., Roe, R.T., 1982. Livestock Disease Survey: A Field Manual for Veterinarians. Australian Government Publishing Service, Camberra, Australia.

Chacón, T., Naranjo, P., 2004. Resultados de plan de control y erradicación de Maedi-visna en la Región de Aysén. Boletín Veterinario Oficial 1, $1-2$.

Comtet, L., Feliziani, F., Lesceu, S., 2010. Validation of the ID Screen ${ }^{\circledR}$ Maedi Visna Indirect ELISA: Specificity on BTV-8 Vaccinated Sheep and Detection of Seroconversion. European Association of Veterinary Laboratory Diagnosticians. Lelystad, The Netherlands, pp. 4-15 (Set. 15-17).

Costa, L.S.P., de Lima, P.P., Callado, A.K.C., do Nascimento, S.A., de Castro, R.S., 2007. Small ruminant lentivirus in Santa Inês ovines: isolation, identification by PCR and serological survey in the State of Pernambuco, Brazil. Arq. Bras. Med. Vet. Zootec. 74, 11-16.

Cutlip, R.C., Jackson, T.A., Laird, G.A., 1977. Immunodifusion test for Ovine progressive pneumonia. Am. J. Vet. Res. 38, 1081-1084.

De la Concha-Bermejillo, J.O., 1997. Maedi-visna and ovine progressive pneumonia. Vet. Clin. North Am. Food Anim. Pract. 13, 13-33.

DeMartini, J.C., De la Concha-Bermejillo, A., Carlson, J.O., Bowen, R.A., 2000. Diseases caused by Maedi-Visna and other Ovine Lentivirus. In: Axford, R.F.E., Bishop, S.C., Nicholas, F.W., Owen, J.B. (Eds.), Breeding for Disease Resistance in Farm Animals. CAB, U.S pp. 301-324.

Extramiana, A.B.L., Gonzalez, N., Cortabarria, M., Garcia, M., Juste, R.A 2002. Evaluation of a PCR technique for the detection of Maedi-Visna proviral DNA in blood, milk and tissue samples of naturally infected sheep. Small Rum. Res. 44, 109-117.

Fallas, D., Dolz, G., Jiménez, C., Montero, D., Prendas, J., Romero, J.J. 2009. Epidemiología de la artritis encefalitis caprina en hatos caprinos lecheros de Costa Rica. Cienc. Vet. 27 (2), 57-70.

FAO (Food and Agriculture Organization of the United Nations), 2012. FAOSTAT database, 〈http://www.fao.org/publications/sofa/es/〉.

Fournier, D., Campbell, J.R., Middleton, D.M., 2006. Prevalence of MaediVisna in culled ewes in Alberta. Can. Vet. J. 47, 460-466.

George, M.E., 1995. Aislamiento y Caracterización del Virus de la Artritis Encefalitis Caprina en Costa Rica. Universidad Nacional, Heredia, Costa Rica.

Gjerset, B., Jonassen, C.M., Rimstad, E., 2007. Natural transmission and comparative analysis of small ruminant lentiviruses in the Norwegian sheep and goat populations. Virus Res. 125, 153-156.

Hüttner, K., Seelman, M., Feldhusen, F., 2010. Prevalence and risk factors for Maedi-Visna in sheep farms in Mecklenburg-Vorpommern. Berl. Münch. Tierärtzl. Wochenschr. 123, 10-14.

Jiménez-Sánchez, C., Montero, D., Villalobos, P., Rojas-Martínez, J.L., Cordero, L., Morales, J.A., Rodríguez-Roque, L., 1992. La ArtritisEncefalitis Caprina; Primer Diagnóstico de esta Retrovirosis en Cabras de Costa Rica. Cienc. Vet. 14, 59-63.

Leginagoikoa, I., 2010. Epidemiología y diagnóstico de infección por el virus Maedi-Visna en diferentes sistemas de explotación ovinos españoles. Instituto Vasco de Investigación y Desarrollo Agrario, Spain.

Lombardi, A.L., Nogueira, A.H.C., Feres, F.C., Paulo, H.P., Castro, R.S., Feitosa F.L.F., Cadioli, F.A., Peiró, J.R., Perri, S.H., Lima, V.F.M., Mendes, L.C. 2009. Ocurrence of Maedi-Visna in sheep from Araçatuba region, SP Brazil. Arq. Bras. Med. Vet. Zootec. 61, 1434-1437.

Martínez, P., Nunes-Costa, J., Sampaio de Souza, T., Valencia de Lima, C.C., De Oliveira, A., Rizaldo, R., Pinheiro, 2011. Serological prevalence of Maedi-Visna in sheep herds in the microregion of Juazeiro-Bahia by agar gel immunodiffusion (AGID). Cienc. Anim. Bras. 12, 322-329.

Menzies, P.I., 2006. The Ontario Sheep Health Program: a structured health management program for intensively reared flocks. Small Rumin. Res. 62, 95-99.

Molina, R.M., Trigo, F.J., Cutlip, R.C., 1986. Estudio serológico de la neumonía progresiva ovina en México. Vet. México 17, 269-273.

Pepin, M., Vitu, C., Russo, P., Mornex, J.F., Peterhans, E., 1998. Maedi-visna virus infection in sheep: a review. Vet. Res. 29, 341-367.

Peterhans, E., Greenland, T., Badiola, J., Harkiss, G., Bertoni, G., Amorena, B., Eliaszewicz, M., Juste, R.A., Krassnig, R., Lafont, J.P., Lenihan, P., Petursson, G., Pritchard, G., Thorley, J., Vitu, C., Mornex, J.F., Pépin, M., 2004. Routes of transmission and consequences of small ruminant lentiviruses (SRLVs) infection and eradication schemes. Vet. Res. 35, 257-274.

Pugh, D.G., 2002. Sheep and Goat Medicine. Saunders Elsevier, Pennsylvania, US.

Robles, C.A., Layana, J.A., Cabrera, R.F., Raffo, F., Cutlip, R.C., 2003. Estudio serológico retrospectivo de Maedi (neumonía progresiva) en ovinos y de Artritis-Encefalitis en caprinos de Patagonia, Argentina. Rev. Med. Vet. (Argentina) 84, 96-99.

Rosadio, R.H., Evermann, J.F., DeMartini, J.C., 1984. A preliminary serological survey of viral antibodies in peruvian sheeps. Vet. Microbiol. 10, 91-96.

Snyder, S.P., DeMartini, J.C., Ameghino, E., Caletti, E., 1983. Coexistence of pulmonary adenomatosis and progressive pneumonia in sheep in the central sierra of Peru. Am. J. Vet. Res. 44, 1334-1338.

Synge, B.A., Ritchie, C.M., 2010. Eradication of Maedi-Visna (MV) from infected sheep flocks and caprine arthritis encephalitis (CAE) from infected goat herds in Great Britain using an ELISA test. Vet. Rec. 167, 739-743. 